\title{
Observational Study of Hemodynamic in Pregnant Women Treated at the First Level of Care Lircay - Huancavelica-Peru 2018
}

\author{
Lina Cardenas-Pineda ${ }^{1}$, Editt Orellana-Jesus ${ }^{2}$, Tula Guerra-Olivares ${ }^{1}$, Doris Quispe ${ }^{3}$, Jenny Mendoza ${ }^{1}$, \\ Antonio Picoy-Gonzales ${ }^{1}$, Alicia Alva Mantari ${ }^{4, *}$ \\ ${ }^{1}$ Universidad Nacional de Huancavelica, Huancavelica, Perú \\ ${ }^{2}$ Hospital Regional Docente Materno Infantil el Carmen, Junin, Perú \\ ${ }^{3}$ Hospital Departamental de Huancavelica, Huancavelica, Perú \\ ${ }^{4}$ Image Processing Research Laboratory (INTI-Lab), Universidad de Ciencias y Humanidades, Lima, Perú
}

Received April 20, 2021; Revised December 31, 2021; Accepted February 8, 2022

\section{Cite This Paper in the following Citation Styles}

(a): [1] Lina Cardenas-Pineda, Editt Orellana-Jesus, Tula Guerra-Olivares, Doris Quispe, Jenny Mendoza, Antonio Picoy-Gonzales, Alicia Alva Mantari , "Observational Study of Hemodynamic in Pregnant Women Treated at the First Level of Care Lircay - Huancavelica-Peru 2018," Universal Journal of Public Health, Vol. 10, No. 1, pp. 97 - 106, 2022. DOI: 10.13189/ujph.2022.100111.

(b): Lina Cardenas-Pineda, Editt Orellana-Jesus, Tula Guerra-Olivares, Doris Quispe, Jenny Mendoza, Antonio Picoy-Gonzales, Alicia Alva Mantari (2022). Observational Study of Hemodynamic in Pregnant Women Treated at the First Level of Care Lircay - Huancavelica-Peru 2018. Universal Journal of Public Health, 10(1), 97 - 106. DOI: 10.13189/ujph.2022.100111.

Copyright $\bigcirc 2022$ by authors, all rights reserved. Authors agree that this article remains permanently open access under the terms of the Creative Commons Attribution License 4.0 International License

\begin{abstract}
This quantitative exploratory study analyzes the hemodynamic status of pregnant women attended at the first level of medical care in Lircay - Huancavelica, 2018. Methodology: observational, retrospective, and longitudinal research with a sample of 85 pregnant women, document review was used as a technique, descriptive statistics were used. Results: pregnant women were young women aged 20 to 30 years (79\%) and adolescents aged 16 to 19 years $(31,76 \%), 50,59 \%$ were first-time mothers and 25,88\% were multiparous; $85,88 \%$ received full supplementation with ferrous sulfate $60 \mathrm{mg}$, plus $400 \mathrm{ug}$ of folic acid. The hematocrit decreased from $43,52 \% \pm 4,84$ in the first trimester to $42,45 \% \pm 4,25$ in the second trimester, decreasing to $42,26 \% \pm 3,57$ in the third trimester; $50 \%$ of the pregnant women had a hematocrit lower than $43,80 \%$ in the first trimester, $42,90 \%$ in the second trimester and $39,90 \%$ in the third trimester. The corrected hemoglobin found was 12,33 $\mathrm{g} / \mathrm{dL} \pm 1,10$ in the first trimester, which dropped to 11,95 $\mathrm{g} / \mathrm{dL} \pm 1,02$ in the second and $11,77 \mathrm{~g} / \mathrm{dL} \pm 1,08$ in the third trimester; $50 \%$ of the pregnant women had hemoglobin below $12,30 \mathrm{~g} / \mathrm{dL}$ in the first trimester, 12,00 $\mathrm{g} / \mathrm{dL}$ in the second and third trimester. Regarding the total,
\end{abstract}

the $3,53 \%$ presented mild anemia in the first trimester, rising to $9,41 \%$ in the second trimester and up to $15,29 \%$ in the third trimester, moderate anemia was minimal $1,18 \%$. Conclusions: the hemodynamics of the pregnant women have suffered decreases in hematocrit and hemoglobin; anemia increased from the first trimester to the third, the hemoglobin reached in the third trimester is a risk factor for puerperal anemia.

Keywords Hematocrito, Hemoglobina, Gestantes, Anemia

\section{Introduction}

Hematological evaluation during pregnancy is important as it allows us to understand the nutritional status and the capacity of the mother to support the fetus. In the present investigation, the behavior of hematocrit and hemoglobin in each trimester of pregnancy has been studied thoroughly, for which the values found in each trimester of pregnancy have been taken, data obtained from the hemogram. 
This population has been chosen because it has a peculiar characteristic in which few cases of anemia have been observed during pregnancy, as can be seen, the great majority complied with the supplementation with ferrous sulfate $60 \mathrm{mg}$ and folic acid $400 \mathrm{ug} / \mathrm{day}$, it is a young and adolescent population.

The collective analysis gives us valuable information on the behavior in this case of hematocrit and hemoglobin of all pregnant women of San Juan de Dios de Ccollpapampa core, the hemogram of 85 pregnant women attended during 2018 was analyzed. It reveals interesting data that makes us think about the practice of iron supplementation and inflammatory processes that limit its absorption. In addition, the behavior of these two elements of the blood by trimester of pregnancy, which we put to your consideration, draws our attention.

Therefore, the present article has four chapters, the first one presents the problem, the second one covers the theoretical framework, the third one contains the methodological aspects and in the fourth chapter we present the results, discussion and the conclusions that we have reached.

\section{Description and Statement of the Problem}

Blood is an indispensable fluid in our organism, and it is composed of liquids such as plasma, water, salts and proteins, whereas the solid part contains red blood cells, white blood cells and platelets. It is necessary that all its components are proportional to fulfill their function as the lack or excess of its components leads the human being to suffer from pathologies.

The hematocrit and hemoglobin are fundamental parts of the blood that fulfill the function of oxygen transport, it catalyzes the reaction between carbon dioxide and water, a situation that makes possible the transport of the dioxide to the lungs. Likewise, deficiency produces anemia and excess polycythemia [1]. In pregnancy it is vital for the survival of the fetus that the mother is in optimal conditions. The elements mentioned in physiological conditions, experience modifications and increase throughout the pregnancy, especially in the second trimester; however, the plasma increases in greater proportion, which causes hemodilution, and these modifications demand nutrients, in particular iron [2].

Anemia in pregnancy is the main complication that has been observed. It is a problem that occurs throughout the world in almost $30 \%$ of pregnant women, intensifying in developing countries such as Peru, where $29.6 \%$ of pregnant women have reported anemia [3]. Therefore, during pregnancy it is important to monitor and track the pregnancy through hemograms for each trimester, and analyze how it is developing, in order to correct risks and deviations opportunely [4], the objective is that the pregnant woman arrives at labor in optimal conditions, to face the expected blood loss during labor, to tolerate without major changes in vital signs, both during and after delivery [5]. In this way, puerperal anemia can be avoided, as this entity manifests itself with less working capacity in the mother, decreased spontaneous physical and motor activity, and in the newborn, with an increased probability of suffering from anemia and alterations in the central nervous system due to insufficient myelination and synthesis of neurotransmitters [6], [7]. Due to the aforementioned conditions, it is necessary to analyze the behavior of hematocrit and hemoglobin during pregnancy in pregnant women in the rural area of the district of Lircay, women living in poverty in the fourth and fifth quartile. The hemogram is one of the indispensable indicators to evaluate the pregnant woman, results that allow us to act immediately to correct any deviation that may occur, however, a collective analysis of hematocrit and hemoglobin gives us valuable information to make decisions at the health facility level and generate local strategies that can later be assumed in macro. In addition, the findings are also useful for in-depth research in larger populations.

\section{Literature Review}

Jimenez et al [8] performed a study aimed at evaluating the prevalence of anemia during pregnancy in Cuba during a period of 15 years. Maternal and infant surveillance was carried out in all the provinces of the country, and three levels of anemia were catalogued at the beginning and third trimester of pregnancy: light (10-10,9 g/dl), moderate $7-9,9 \mathrm{~g} / \mathrm{dl})$ and severe $(<7 \mathrm{~g} / \mathrm{dl})$. Results: During the first trimester there was a decrease in anemia of $44,6 \%$ and in the third trimester the decrease was $45,3 \%$. Although it is a public health problem, the evaluation from 1996 to 2011 has been decreasing progressively.

Manjarres et al [7], published in 2012 a study whose objective was to evaluate the biochemical indicators of nutritional status, iron and folate in a group of pregnant women linked to a nutritional program, developed in Antioquia - Colombia, in a poor population, which included 26 pregnant women, within the indicators they measured hemoglobin applying ANOVA for comparison between trimesters of gestation, $\mathrm{p}<0.05$; the average hemoglobin concentration in the first trimester was 12,6 \pm $0,17 \mathrm{~g} / \mathrm{dl}$, in the second trimester $11,5 \pm 0,18 \mathrm{~g} / \mathrm{dl}$ and 11,7 $\pm 0,20 \mathrm{~g} / \mathrm{dl}$ in the third trimester. In the third trimester four cases of anemia were found. The nutrients showed positive effects on the biochemical indicators such as hemoglobin.

Gonzales, et al [9], in 2019 published an article on the pathophysiology of anemia during pregnancy, after having evaluated the hemodynamic changes during a period, from 2012 to 2017 in pregnant women living above 1290 m.a.s.l. one of the characteristics evaluated was the hemoglobin corrected by trimesters, in the first trimester the average of this was $12,22 \pm 0,01 \mathrm{~g} / \mathrm{dl} \quad(\mathrm{n}=164396)$, in the second 
trimester was of $11,78 \pm 0,01 \mathrm{~g} / \mathrm{dl}(\mathrm{n}=553978)$ and finally in the third semester was $11,54 \pm 0,01 \mathrm{~g} / \mathrm{dl}(\mathrm{n}=994265)$.

Ampuero et al [10], in 2018 published a research article whose objective was to determine the relationship between iron intake and hemoglobin level in postpartum women at the National Hospital Hipolito Unanue, it was an observational, correlational, cross-sectional design, and the sample consisted of 100 pregnant women in the last trimester during the period March-April 2018. The average iron intake was of 4,223 $\mathrm{g} \pm 1,9841$ for the heminic and $11,652 \mathrm{~g} \pm 3,1356$ for the non-heminic; mean hemoglobin level had an average of $11,591 \mathrm{~g} / \mathrm{dL} \pm 0,9343$. A significant association was found between hemoglobin level and iron intake when the Spearman correlation coefficient was applied. The higher the dietary iron intake, the higher the hemoglobin level.

Cardenas [11], in 2017 carried out a study to determine whether anemia in pregnant women is a risk factor associated with low birth weight, this study was observational, analytical, retrospective, longitudinal case-control study, with a population of 1547 pregnant women from January 2014 to December 2015 at the National Police Hospital Luis N. Saenz; however, 160 were included, the odds ratio (OR) measures were analyzed, 95\% confidence interval and chi-square was applied. In the first and third trimester, hemoglobin levels below $11 \mathrm{~g} / \mathrm{dL}$ were classified as anemia, while in the second trimester values were below $10,5 \mathrm{~g} / \mathrm{dL}$. In the first trimester 27 pregnant women had anemia, in the second 15 and in the third trimester 13. It was concluded that anemia during the first and third trimester of pregnancy is a risk factor for low birth weight.

Vasquez et al [12], in 2009 conducted a retrospective, observational and correlational study associating hemoglobin with maternal and newborn characteristics, they used the medical records of pregnant women attended at the Regional Hospital of Loreto in 2008; hemoglobin levels were measured in two trimesters, one of which was necessarily the third trimester. In the second and third trimester, hemoglobin levels of 11 to $13 \mathrm{~g} / \mathrm{dL}$ predominated in $72,2 \%$ and $96,6 \%$ respectively.

Canalejo, et al[13], in an article entitled "Reference values of the hematocrit in pregnant women, with current technology", a study conducted in Argentina in 2007, in 435 clinically healthy pregnant women, it was found that the average hematocrit was in the range of $37 \pm 0,02$ in the first trimester, $36 \pm 0,02$ in the second trimester, $0,36 \pm$ 0,02 in the third semester; and hemoglobin is located at $12,3 \pm 0,66$ in the first trimester, $12,1 \pm 0,70$ in the second one, and 11,9 $\pm 0,65$ in the first trimester. Erythrocyte counts, hemoglobin concentration and hematocrit decreased significantly between the first and third trimester $(\mathrm{p}<0,01)$. This is related to the greater plasma expansion relative to that of globular mass, which occurs during gestation. The hemoglobin from the first to the second trimester decreased by $2,2 \%(p<0,01)$, from the second to the third semester up to $1,5 \%$ and from the first and the third semester decreased by $3,4 \%(p<0,001)$.

\section{Conceptual Foundations}

\section{Hemoglobin}

Erythrocytes perform one of the vital functions that is the gaseous exchange of oxygen and carbon dioxide between the lungs and tissues, within them we find globular proteins called hemoglobins whose function is to fix oxygen in the lungs and transport it through the blood to the tissues and cells surrounding the capillary bed of the vascular system; on its return to the lungs, hemoglobin transports carbon dioxide and protons [14], [15]. Hemoglobin was the first protein to be crystallized and associated with a specific function, a fact that occurred in 1849 and one of the first proteins whose molecular weight was correctly determined, in 1958 it was synthesized for the first time in vitro and its structure was established in 1960 [16] [14].

Hemoglobin has four polypeptide chains, each of these chains contains a heme group (non-polypeptide portion of a protein), contains an iron atom in the ferrous oxidation state $(+2)$ and can form five or six bonds [14], [16]. More than $95 \%$ of the hemoglobin of adults and children older than 7 months is A ( $\mathrm{HbA})$, it has two $\alpha$ and two $\delta$ chains; in a small percentage ( 2 to $3 \%$ ) there is $\mathrm{HbA} 2$, has two $\alpha$ and two $\delta$ chains [14]. Fetal and newborn hemoglobin has two $\alpha$ and two $\mathrm{V}$ chains, therefore it binds oxygen more strongly; there are also Gower I, Gower II and Portland hemoglobins, which are embryonic and appear in the first trimester of gestation [14].

Oxygen $\mathrm{O} 2$ is not sufficiently soluble in the blood so it needs hemoglobin to be transported. One liter of blood contains 150 grams of $\mathrm{Hb}$ and each gram of $\mathrm{Hb}$ dissolves $1.34 \mathrm{ml}$ of $\mathrm{O} 2$; per liter of blood $200 \mathrm{ml}$ of $\mathrm{O} 2$ are transported, therefore, if there were no hemoglobin, the blood would have to circulate 87 times faster than usual [14].

World Health Organization and the National Institute of Health proposed that hemoglobin values should be adjusted according to the altitude above sea level, which they live to have a more accurate diagnosis Fig 1 . 


\begin{tabular}{|c|c|c|c|c|c|}
\hline Height & $\begin{array}{c}\text { Adjustment } \\
\text { factor for height }\end{array}$ & Height & $\begin{array}{c}\text { Adjustment } \\
\text { factor for height }\end{array}$ & Height & $\begin{array}{c}\text { Adjustment } \\
\text { factor for height }\end{array}$ \\
\hline 1000 & 0.1 & 2400 & 1.1 & 3800 & 3.1 \\
\hline 1100 & 0.2 & 2500 & 1.2 & 3900 & 3.2 \\
\hline 1200 & 0.2 & 2600 & 1.3 & 4000 & 3.4 \\
\hline 1300 & 0.3 & 2700 & 1.5 & 4100 & 3.6 \\
\hline 1400 & 0.3 & 2800 & 1.6 & 4200 & 3.8 \\
\hline 1500 & 0.4 & 2900 & 1.7 & 4300 & 4.0 \\
\hline 1600 & 0.4 & 3000 & 1.8 & 4400 & 4.2 \\
\hline 1700 & 0.5 & 3100 & 2.0 & 4500 & 4.4 \\
\hline 1800 & 0.6 & 3200 & 2.1 & 4600 & 4.6 \\
\hline 1900 & 0.7 & 3300 & 2.3 & 4700 & 4.8 \\
\hline 2000 & 0.7 & 3400 & 2.4 & 4800 & 5.0 \\
\hline 2100 & 0.8 & 3500 & 2.6 & 4900 & 5.2 \\
\hline 2200 & 0.9 & 3600 & 2.7 & 5000 & 5.5 \\
\hline 2300 & 1.0 & 3700 & 2.9 & & \\
\hline
\end{tabular}

Figure 1. Adjustment for hemoglobin height. Data obtained from the Technical Guide: Clinical Practice Guideline for the diagnosis and treatment of iron deficiency anemia in children and adolescents in primary health care facilities [4]

Table 1. Hemoglobin control scheme during pregnancy

\begin{tabular}{|c|c|c|c|}
\hline \multicolumn{4}{|c|}{ Hemoglobin control scheme during pregnancy } \\
\hline $\begin{array}{c}\text { 1st Hemoglobin } \\
\text { Measurement }\end{array}$ & $\begin{array}{c}\text { 2nd Hemoglobin } \\
\text { Measurement }\end{array}$ & 3rd Hemoglobin Measurement & 4th Hemoglobin Measurement \\
\hline $\begin{array}{c}\text { During the first prenatal } \\
\text { check-up (start of } \\
\text { supplementation) }\end{array}$ & Week 25 to 28 of gestation. & $\begin{array}{c}\text { Week 37 to 40 of gestation } \\
\text { (before delivery) }\end{array}$ & $\begin{array}{c}\text { At 30 days after delivery (end of } \\
\text { supplementation) }\end{array}$ \\
\hline
\end{tabular}

Technical standard-Therapeutic and preventive management of anemia in children, adolescents, pregnant and postpartum women [4].

\section{Hemoglobin in pregnancy}

Pregnancy is a physiological situation that generates a demand for iron supply, ranging from $0,85 \mathrm{~g} /$ day in the first trimester to $7,5 \mathrm{~g} /$ day in the third trimester. The absorption of heme iron is well available and takes place at the gastrointestinal level. In pregnant women, absorption increases with increasing duration of pregnancy, especially after 20 weeks of pregnancy, but women with ample reserves of this element will not show the same increase as in pregnant women with few reserves. Hemoglobin shows a constant fall from the end of the first trimester due to hemodilution (increase in plasma volume greater than the erythrocyte mass) until approximately 25 weeks of gestation, then it rises until it reaches maximum values before delivery [9].

The values will be taken during the first prenatal care, a second one will be taken after three months and the third one will be taken before delivery, there will be a fourth one taken 30 days after delivery; if the pregnant woman starts prenatal care after 32 weeks, the hemoglobin will be taken during this care, if it is within normal values, a second measurement will be taken between 37 and 40 weeks and the last one 30 days after delivery. If, when adjusting the values in any of the measurements, it is detected that they are below $11 \mathrm{~g} / \mathrm{dl}$, a physician, nutritionist or health professional trained in nutritional counseling should be consulted [4]. The hemoglobin control scheme during pregnancy is shown in Table 1.

\section{Hematocrit}

Volume that represents the red cells with respect to the total blood, it can be multiplied the value of hemoglobin by 3 ; the manual hematocrit obtained from the centrifugation of a blood column ( \pm 3\%) should be differentiated from the one obtained by calculations in the automatic analyzer [20]. When the hematocrit is less than $32 \%$ during the second trimester or $33 \%$ in the first and third trimester it is defined as gestational anemia obviously 
accompanied by a decrease in hemoglobin to levels less than $11 \mathrm{~g} / \mathrm{dL}[17]$.

\section{Hematologic changes during pregnancy}

The blood volume increases during pregnancy by 40 to $45 \%$ in comparison to before pregnancy, this expansion is very varied, in some it is minimal and in others can even duplicate, the presence of a fetus is not indispensable for the appearance of volemia since in molar pregnancies the same changes occurred. Hypervolemia has several functions such as: covering the placental uterus, which requires an average of 500 to $600 \mathrm{ml} /$ minute, protecting the mother and fetus against alterations in venous return in the supine and erect position, safeguarding the mother against the adverse effects of blood loss due to childbirth. The increase is throughout the pregnancy, $15 \%$ occurs in the first $12 \mathrm{ss}$, in the second trimester the volume expands rapidly and then in the third trimester it slows down. The expansion of blood volume is a consequence of the increase in plasma and erythrocytes, although the latter is not in the same proportion, which explains the hemodilution. However, it should be noted that at the beginning of the third trimester there is an increase of erythropoietin in the maternal plasma, and this corresponds to a maximum erythrocyte production in this trimester. This leads us to believe that the hematocrit count should increase. However, despite the increased erythropoiesis, hemoglobin concentration and hematocrit decrease slightly during normal pregnancy. The hemoglobin concentration in pregnancies at term is $12.5 \mathrm{~g} / 100 \mathrm{ml}$ and $6 \%$ of pregnant women are below $11.0 \mathrm{~g} / 100 \mathrm{ml}$, a value that in late stages should be considered abnormal [18].

\section{Iron supplementation}

From the 14th week of gestation until 30 days after delivery, iron and folic acid or polymalted iron should be administered, hemoglobin levels should be maintained above $11 \mathrm{gr} / \mathrm{dl}$, the ferrous sulfate tablet contains $60 \mathrm{mg}$ of elemental iron and 400 ug of folic acid, in case the pregnant woman has not started in the 14th week, she will do it immediately after the first prenatal care. If prenatal care begins after the 32nd week, the daily dose will be doubled to $120 \mathrm{mg}$ of elemental iron plus $800 \mathrm{ug}$ of folic acid for three months [4]. Nevertheless, controversy has arisen regarding iron supplementation in pregnant women without anemia as iron, although it is indispensable in adequate amounts, when it exceeds the required limits of 2 to $4.8 \mathrm{~g} /$ day during pregnancy it has harmful effects on the mother and the fetus, thus hemodilution plays an important role in the adequate distribution of iron. It is known that $10 \%$ of the iron ingested is absorbed, a reference value that can change according to the amount of hepcidin in plasma. Hepcidin is a hormone produced in the liver that blocks iron absorption, increases in situations of inflammation and iron excess, and decreases in hypoxia, altitude, pregnancy, iron deficiency, testosterone and in smokers.

On the other hand, the supplements used could be referred to be above the daily requirements, the supplementation should be from 20 to $48 \mathrm{mg} / \mathrm{day}$, this situation suggests that a better analysis of the supplementation is required [2]. This is summarized in Table 2.

Hemodynamics of the pregnant woman: it is the situation of blood movement through the vascular system, in this case we will study its components such as hemoglobin and hematocrit [14].

Hemoglobin: protein that contains four polypeptide chains, each of which has a heme group. Its function is to fix oxygen in order to be transported to the tissues and cells, during pregnancy to the intervillous bed of the placenta.

Hematocrit: red blood cell volume in relation to total blood, in pregnancy it should not be below $32 \%$ in the second trimester and $33 \%$ in the first and third trimester [20].

VARIABLE Pregnant hemodynamics. In the following Table 3 you can see a summary of the construction of the variable.

Table 2. Iron and folic acid supplementation in pregnant and puerperal women

\begin{tabular}{|c|c|c|c|}
\hline \multicolumn{4}{|c|}{ Iron and folic acid supplementation } \\
\hline Start of administration & Dose & Product & Duration \\
\hline $\begin{array}{l}\text { Pregnant women from the } 14 \text { th } \\
\text { week of gestation }\end{array}$ & $\begin{array}{c}60 \mathrm{mg} \text { elemental iron } \\
+ \\
400 \mathrm{ug} \text { of folic acid }\end{array}$ & \multirow{3}{*}{$\begin{array}{c}\text { Ferrous Sulfate Tablet } \\
+ \\
\text { Folic Acid } \\
\text { Or } \\
\text { Tablet of Polyimaltosated } \\
\text { Iron } \\
+ \\
\text { Folic acid }\end{array}$} & $\begin{array}{l}1 \text { tablet per day up to } 30 \text { days after } \\
\text { delivery }\end{array}$ \\
\hline $\begin{array}{l}\text { Pregnant women starting } \\
\text { prenatal care after the } 32 \mathrm{nd} \\
\text { week. }\end{array}$ & $\begin{array}{c}120 \text { mg elemental iron } \\
+ \\
800 \text { ug of folic acid }\end{array}$ & & $\begin{array}{l}2 \text { tablets per day up to } 30 \text { days after } \\
\text { delivery }\end{array}$ \\
\hline Puerperal & $\begin{array}{c}60 \mathrm{mg} \text { elemental iron } \\
+ \\
400 \mathrm{ug} \text { of folic acid }\end{array}$ & & $\begin{array}{l}1 \text { tablet per day up to } 30 \text { days after } \\
\text { delivery }\end{array}$ \\
\hline
\end{tabular}

Technical standard-Therapeutic Management and prevention of anemia in children, adolescents, pregnant and puerperal women [15]. 
Table 3. Variable

\begin{tabular}{|c|c|c|c|c|c|}
\hline \multicolumn{6}{|c|}{ PREGNANT HEMODYNAMICS } \\
\hline $\begin{array}{l}\text { CONCEPTUAL } \\
\text { DEFINITION }\end{array}$ & $\begin{array}{l}\text { OPERATIONA } \\
\text { L DEFINITION }\end{array}$ & INDICATORS & ITEMS & VALUE & Variable type \\
\hline \multirow{10}{*}{$\begin{array}{l}\text { It is the situation of } \\
\text { blood movement } \\
\text { through the vascular } \\
\text { system, which is } \\
\text { influenced by its } \\
\text { elements, formed cells, } \\
\text { plasma volume, blood } \\
\text { viscosity and vascular } \\
\text { state. }\end{array}$} & \multirow{10}{*}{$\begin{array}{l}\text { It is the behavior } \\
\text { of two elements } \\
\text { of maternal } \\
\text { blood; hematocrit } \\
\text { and hemoglobin } \\
\text { by trimester of } \\
\text { pregnancy. }\end{array}$} & \multirow{2}{*}{$\begin{array}{l}\text { Characteristics of the } \\
\text { pregnant woman }\end{array}$} & Age & Numeric & Discreet \\
\hline & & & Parity & Numeric & Discreet \\
\hline & & \multirow{2}{*}{ Sulfate supplementation } & Complete & \multirow{2}{*}{$\begin{array}{c}\text { Categorica } \\
1\end{array}$} & \multirow{2}{*}{ Nominal } \\
\hline & & & Incomplete & & \\
\hline & & \multirow{3}{*}{ Hematocrit (\%) } & Control in the first trimester & Numeric & Discreet \\
\hline & & & $\begin{array}{l}\text { Control in the second } \\
\text { trimester }\end{array}$ & Numeric & Discreet \\
\hline & & & Control in the third trimester & Numeric & Discreet \\
\hline & & \multirow{3}{*}{ Hemoglobin (gr/dl) } & Control in the first trimester & Numeric & Discreet \\
\hline & & & $\begin{array}{l}\text { Control in the second } \\
\text { trimester }\end{array}$ & Numeric & Discreet \\
\hline & & & Control in the third trimester & Numeric & Discreet \\
\hline
\end{tabular}

\section{Methodology and Results}

\section{Temporal and Spatial Scope}

The San Juan de Dios de Ccollpapampa Core is located in the square of the town center of the same name, district of Lircay, province of Angaraes and region Huancavelica, located at 3300.0.00 meters above sea level. It borders to the south with the district of Lircay and Anchonga, to the north with the town center of Challhuapuquio, to the west with the town center of Pircapahuana and Uchucupampa, and to the east with the town center of Perccapampa. It is accessed by land from the center of the city of Lircay, in an approximate distance of $5 \mathrm{~km}$, a 15 -minute drive and an approximate 1-hour walk. It is a category 1 - II IPRESS, which has all the primary care package, the IPRESS has medical offices, Obstetrics, Dentistry, Nursing, Pharmacy, Triage and Emergencies, and the laboratory service is performed by the Hospital of Lircay. As a nucleus, it is in charge of 6 IPRESS, Anchonga, Perccapampa, Uchcupampa, Challhuapuquio, Pircapahuana and San Juan de Dios de Ccollpapampa. The population served is of precarious economic resources (third and fourth quintile), almost all of whom are beneficiaries of comprehensive health insurance.

RESEARCH TYPE: The research is observational since data was collected through an analysis of the medical records of pregnant women attended in 2018, likewise it is retrospective, of longitudinal cut since the data of hemoglobin and hematocrit were taken in each trimester of pregnancy [21].

RESEARCH LEVEL: It is descriptive as we present the characteristics of hemoglobin and hematocrit of pregnant women in the different trimesters attended at the first level of care in Lircay during 2018, as found in their natural state [22].

POPULATION, SAMPLE AND SAMPLING: Population: it consisted of 85 pregnant women. Study sample or sample size: the analysis of the clinical histories of all the pregnant women was carried out, for this reason our sample was a census.

INSTRUMENT AND TECHNIQUE FOR DATA COLLECTION: A document review form was used as an instrument, and the technique used was document review, evaluating all the medical records of the pregnant women who had blood counts in each trimester of pregnancy.

\section{DATA ANALYSIS TECHNIQUES AND} PROCESSING: Descriptive statistics were processed using Microsoft Excel spreadsheet, through which the results were organized in one-entry tables with absolute frequency distributions. The SPSS 21 system was also used, the results are presented organized in tables of one and two entries with absolute and percentage frequency distributions.

\section{Results}

Table 4. Characteristics of pregnant women attended at the first level of care in Lircay - Huancavelica in 2018

\begin{tabular}{|c|c|c|}
\hline \multirow{2}{*}{$\begin{array}{c}\text { Pregnant women } \\
\text { characteristics }\end{array}$} & \multicolumn{2}{|c|}{ Total number of pregnant women } \\
\cline { 2 - 3 } & $\mathrm{f}=85$ & $\%$ \\
\hline \multirow{3}{*}{ Age Group } \\
\hline 16 - 19 years & 27 & 31,76 \\
\hline 20 - 30 years & 50 & 58,82 \\
\hline > a 30 years & 8 & 9,42 \\
\hline \multirow{2}{*}{ Parity } \\
\hline Primiparous & 43 & 50,59 \\
\hline Multiparous & 22 & 25,88 \\
\hline Great Multiparous & 20 & 23,53 \\
\hline Ferrous Sulfate Supplementation \\
\hline Incomplete & 12 & 14,12 \\
\hline Complete & 73 & 85,88 \\
\hline
\end{tabular}


The predominant age group was 20 to 30 years, representing $58,82 \%$ of pregnant women, followed by the age group 16 to 19 years with $31,76 \%$ (which can be seen in Table 4). Regarding parity, it was found that primiparous women predominated with $50,59 \%$, followed by multiparous women with $25,88 \%$. Most of the pregnant women received complete supplementation $73(85,88 \%)$ with ferrous sulfate $60 \mathrm{~g}$, plus $400 \mathrm{ug}$ of folic acid.

Table 5 shows that the average hematocrit is $43,52 \%$ in the first trimester, $42,45 \%$ in the second one and of $42,26 \%$ in the third trimester, with a standard deviation of $4,84 \%, 4,25 \%$ and $3,57 \%$ in each trimester respectively; $50 \%$ of the pregnant women had a hematocrit lower than $43,80 \%$ in the first trimester, $42.90 \%$ in the second one and of $39,90 \%$ in the third trimester, the most frequent hematocrit was $43,20 \%$ in the first trimester $42,90 \%$ in the second one and of $39.90 \%$ in the third trimester.
Table 5. Behavior of hematocrit by trimester of pregnancy of pregnant women attended at the first level of care Lircay - Huancavelica in 2018

\begin{tabular}{|c|c|c|c|}
\hline \multicolumn{4}{|c|}{ HEMATOCRIT } \\
\hline & $\begin{array}{c}\text { First } \\
\text { Trimester }\end{array}$ & $\begin{array}{c}\text { Second } \\
\text { Trimester }\end{array}$ & $\begin{array}{c}\text { Third } \\
\text { Trimester }\end{array}$ \\
\hline & $\mathbf{N}=\mathbf{8 5}$ & $\mathbf{N = 8 5}$ & $\mathbf{N}=\mathbf{8 5}$ \\
\hline Mean & $43,52 \%$ & $42,45 \%$ & $42,26 \%$ \\
\hline Median & $43,80 \%$ & $42,90 \%$ & $42,60 \%$ \\
\hline Mode & $43,20 \%$ & $42,90 \%$ & $39,90 \%$ \\
\hline Standard Deviation & $4,84 \%$ & $4,25 \%$ & $3,57 \%$ \\
\hline
\end{tabular}

The Figure 2 highlights the fact that the hematocrit in the first trimester is higher than in the second and third trimesters, and that it decreases as gestational age advances, with a decrease of $1.07 \%$ from the first to the second trimester, $0.19 \%$ from the second to the third trimester, and $1.26 \%$ from the first to the third trimester.

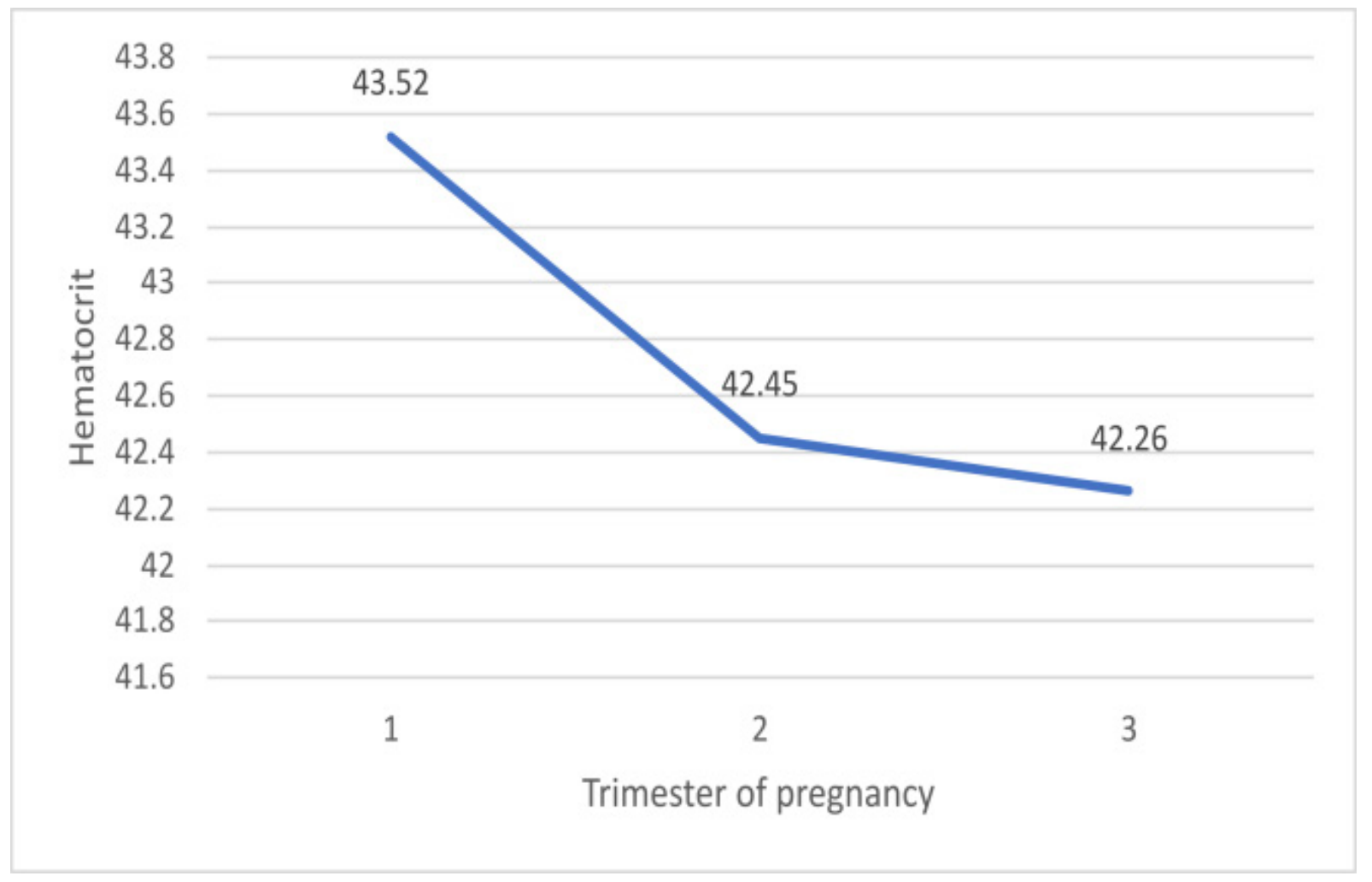

Figure 2. Hematocrit behavior by trimester of pregnancy in pregnant women attended at the first level of care Lircay - Huancavelica during the year of 2018 . 


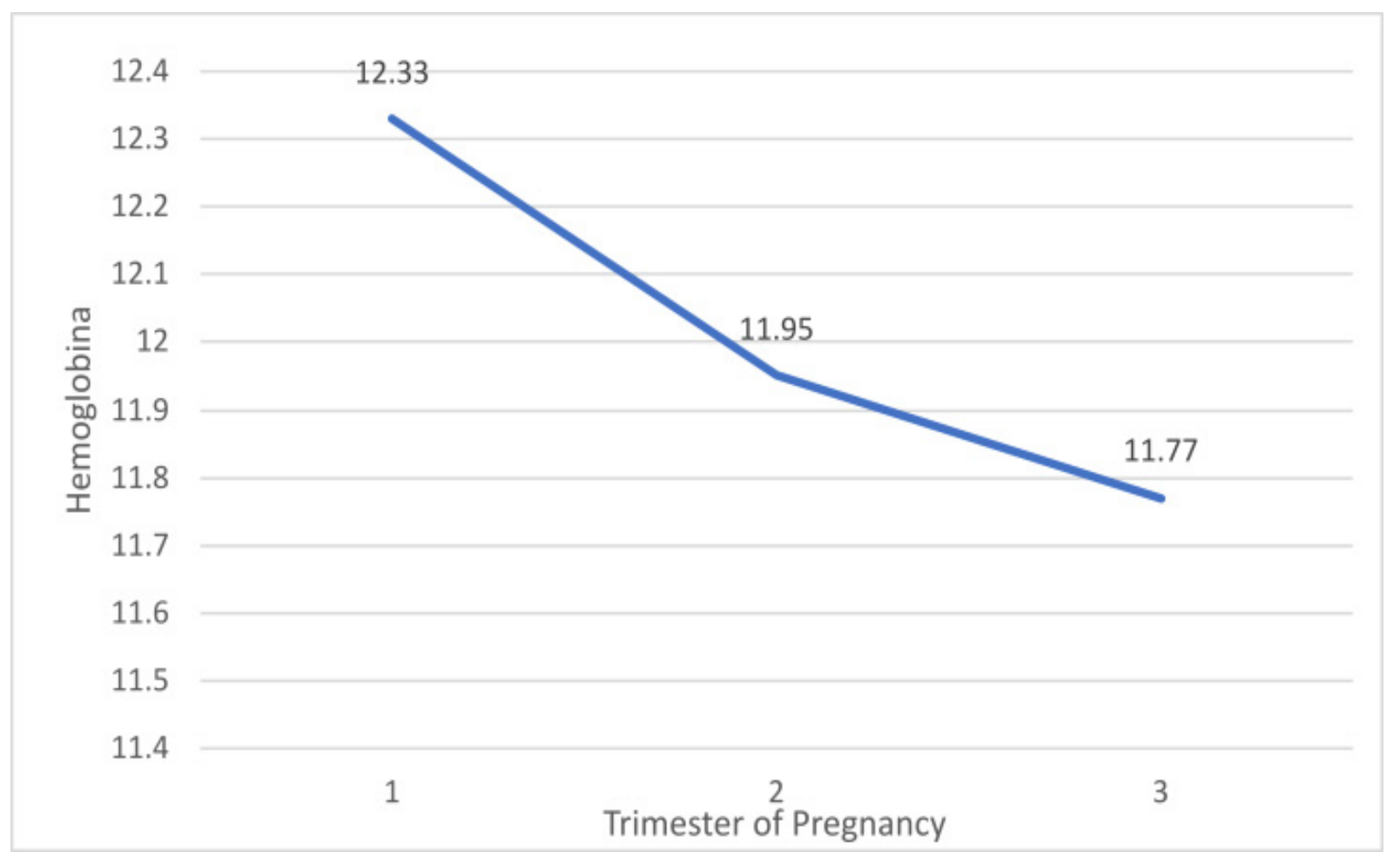

Figure 3. Hemoglobin behavior by trimester of pregnancy of pregnant women attended at the first level of care in Lircay - Huancavelica during the year of 2018 .

Table 6. Hemoglobin behavior by trimester of pregnancy in pregnant women attended at the first level of care in Lircay - Huancavelica in the year of 2018

\begin{tabular}{|c|c|c|c|}
\hline \multicolumn{4}{|c|}{ CORRECTED HEMOGLOBIN } \\
\hline & $\begin{array}{c}\text { First } \\
\text { Trimester }\end{array}$ & $\begin{array}{c}\text { Second } \\
\text { Trimester }\end{array}$ & $\begin{array}{c}\text { Third } \\
\text { Trimester }\end{array}$ \\
\hline & $\mathbf{N}=\mathbf{8 5}$ & $\mathbf{N}=\mathbf{8 5}$ & $\mathbf{N}=\mathbf{8 5}$ \\
\hline Mean & $12,33 \mathrm{~g} / \mathrm{dl}$ & $11,95 \mathrm{~g} / \mathrm{dl}$ & $11,77 \mathrm{~g} / \mathrm{dl}$ \\
\hline Median & $12,30 \mathrm{~g} / \mathrm{dl}$ & $12,00 \mathrm{~g} / \mathrm{dl}$ & $12,00 \mathrm{~g} / \mathrm{dl}$ \\
\hline Mode & $13,00 \mathrm{~g} / \mathrm{dl}$ & $12,00 \mathrm{~g} / \mathrm{dl}$ & $12,00 \mathrm{~g} / \mathrm{dl}$ \\
\hline Standard Deviation & $1,10 \mathrm{~g} / \mathrm{dl}$ & $1,023 \mathrm{~g} / \mathrm{dl}$ & $1,08 \mathrm{~g} / \mathrm{dl}$ \\
\hline
\end{tabular}

In the Table 6 shows that the average hemoglobin was $12,33 \mathrm{~g} / \mathrm{dL}$ in the first trimester, $11,95 \mathrm{~g} / \mathrm{dL}$ in the second trimester and $11,77 \mathrm{~g} / \mathrm{dL}$ in the third trimester with a standard deviation of $1,10 \mathrm{~g} / \mathrm{dL}, 1,02 \mathrm{~g} / \mathrm{dL}$ and $1,08 \mathrm{~g} / \mathrm{dL}$ in each trimester respectively; $50 \%$ of the pregnant women had hemoglobin below $12,30 \mathrm{~g} / \mathrm{dL}$ in the first trimester, $12,00 \mathrm{~g} / \mathrm{dL}$ in the second and third trimesters, the most common hemoglobin in the first trimester was $13 \mathrm{~g} / \mathrm{dL}$, while in the second and third trimesters it was $12 \mathrm{~g} / \mathrm{dL}$.

In the Figure 3, on average, first trimester hemoglobin decreases from $12.33 \mathrm{~g} / \mathrm{dl}$ to $11.95 \mathrm{~g} / \mathrm{dl}$ in the second trimester, reaching $11.77 \mathrm{~g} / \mathrm{dl}$ in the third trimester; a decrease of $0.56 \mathrm{~g} / \mathrm{dl}$ is observed from the first to the third trimester.

In Table 7 , it can be appreciated that $3.53 \%$ of the pregnant women in the first trimester presented light anemia, $1.18 \%$ moderate anemia, in the second trimester light anemia increased to $9.41 \%$, and $1.18 \%$ severe anemia, increasing to $15.29 \%$ in the third trimester mild anemia, and $1.18 \%$ moderate anemia was obtained.

Table 7. Anemia by trimester of pregnancy in pregnant women attended at the first level of care Lircay - Huancavelica in 2018 in accordance with parity.

\begin{tabular}{|c|c|c|c|c|c|c|}
\hline \multicolumn{7}{|c|}{ Anemia por trimestre } \\
\hline \multirow{2}{*}{ Condition } & \multicolumn{2}{|c|}{$\begin{array}{c}\text { First } \\
\text { Trimester }\end{array}$} & \multicolumn{2}{c|}{$\begin{array}{c}\text { Second } \\
\text { Trimester }\end{array}$} & \multicolumn{2}{c|}{$\begin{array}{c}\text { Third } \\
\text { Trimester }\end{array}$} \\
\cline { 2 - 7 } & $\mathbf{N}$ & $\mathbf{\%}$ & $\mathbf{N}$ & $\mathbf{\%}$ & $\mathbf{N}$ & $\mathbf{\%}$ \\
\hline No anemia & 81 & 95.29 & 76 & 89.41 & 71 & 83.53 \\
\hline Light & 3 & 3.53 & 8 & 9.41 & 13 & 15.29 \\
\hline Moderate & 1 & 1.18 & 0 & 0.00 & 1 & 1.18 \\
\hline Severe & 0 & 0.00 & 1 & 1.18 & 0 & 0.00 \\
\hline TOTAL & $\mathbf{8 5}$ & $\mathbf{1 0 0 . 0 0}$ & $\mathbf{8 5}$ & $\mathbf{1 0 0 . 0 0}$ & $\mathbf{8 5}$ & $\mathbf{1 0 0 . 0 0}$ \\
\hline
\end{tabular}

\section{Discussion}

The conditions to analyze the association of an anomaly previous to an earthquake must be fulfilled as follows: 1.) To be related to the deformation previous to the seismic movement. 2.) To be observed in at least. The hematocrit and hemoglobin of a pregnant woman physiologically suffer changes, due to the modifications that occur during pregnancy, there is an increase in plasma volume, while the erythrocyte mass does not increase in the same magnitude as the plasma, which leads the pregnant woman 
to hemodilution, resulting in a slight decrease in hematocrit, decreased blood viscosity and greater availability of nitric oxide to promote utero-placental flow [2]. While the literature mentions that there is a decrease in the second trimester, and then it recovers in the third trimester close to the value of the first trimester. This phenomenon always occurs when the mother has sufficient iron supply or reserve in the second trimester, and the amount of hepcidin in the plasma plays an important role $[2,23]$.

The present study was developed in a first level of care facility in the province of Angaraes, department of Huancavelica, which is located in a rural area, the pregnant women studied are mostly young women aged 20 to 30 years $58,82 \%$ and adolescents aged 16 to 19 years $31.76 \%$, almost half are primiparous $50.59 \%$, while multiparous are $25.88 \%$ and great multiparous are $23.53 \% ; 14.12 \%$ received incomplete supplementation and $85.88 \%$ in complete form, numbers above the average of the region $40 \%$ and the country's reported $61.8 \%$ stated by the ENDES of 2017 [3][3]. When evaluating the behavior of the hematocrit by trimester of pregnancy, an average of $43.52 \% \pm 4.84$ was found in the first trimester, $42.45 \% \pm$ 4.25 in the second trimester and $42.26 \% \pm 3.57$ in the third trimester, as can be seen in the graph. On the other hand, Canalejo, et al [14], found values lower than ours in average $37 \pm 02$ in the first trimester, $36 \pm 02$ in the second trimester, $36 \pm 02$, which could be caused by the altitude in which the pregnant women live as the city of Buenos Aires is located at 25 meters above sea level. In addition, there was a decrease from the first to the second trimester by $1.07 \%$ and from the second to the third by $0.19 \%$, decreasing from the first to the third trimester by $1.26 \%$. However, Canalejo, et al [13], have found that the hematocrit decreases by $1 \%$ from the first to the second trimester, and then the hematocrit is maintained until the third trimester. In this regard, Cunningham et al [22] affirms that this is due to the disproportionate increase in blood volume in which plasma increases more than erythrocytes, generating a hemodilution that physiologically is more accentuated in the second trimester, to recover before delivery, which is not evident in any of the studies, despite the fact that most of the pregnant women have received iron supplementation. This situation suggests that it is probably related to inflammatory processes, a circumstance that would cause the increase of hepcidin in the plasma, blocking the absorption of iron [24] [23]. When analyzing corrected hemoglobin by trimester of pregnancy, we found $12,33 \mathrm{~g} / \mathrm{dL} \pm 1,10$ in the first trimester, $11,95 \mathrm{~g} / \mathrm{dL} \pm 1,02$ in the second trimester and $11,77 \mathrm{~g} / \mathrm{dL} \pm 1,08$ in the third trimester, similar values reported by Manjarrés et al [7] 12,6 $\pm 0,17 \mathrm{~g} / \mathrm{dL}$ in the first trimester, $11,5 \pm 0,18 \mathrm{~g} / \mathrm{dL}$ in the second and 11,7 $\pm 0,20$ $\mathrm{g} / \mathrm{dL}$ in the third trimester, and a slight increase in hemoglobin is observed from the second trimester to the third; in the case of our study, hemoglobin in the second trimester decreases more in the third trimester. Likewise,
Gonzales, et al [24] found values similar to our study, in the first trimester $12,22 \pm 0,01 \mathrm{~g} / \mathrm{dL}$, in the second trimester $11,78 \pm 0,01 \mathrm{~g} / \mathrm{dL}$, in the third trimester $11,54 \pm$ $0,01 \mathrm{~g} / \mathrm{dL}$, and the same progressive decrease in each trimester. On the other hand, Canalejo, et al [13] also finds a progressive decrease in each trimester from $12,3 \pm 0,66$ in the first trimester, to $12,1 \pm 0,70$ in the second trimester, and $11,9 \pm 0,65$ in the third trimester; as it can be seen from the three studies reviewed in two there is a progressive decrease in each trimester, while in one it is shown a minimal increase, consistent with the hematological changes in pregnancy [17]. Nonetheless, the progressive decrease found from the first to the third trimester in three studies, including ours, is remarkable, although most of them receive iron supplementation, which invites us to evaluate these aspects in depth in future studies. On the other hand, a hemoglobin of $11.77 \%$ in the third trimester will be able to withstand the blood loss that occurs physiologically during labor and the puerperium.

On the other hand, the proportion of pregnant women with anemia by trimester was evaluated showing a very low $3.53 \%$ of mild anemia in the first trimester, which increased progressively reaching $9.41 \%$ in the second trimester and $15.29 \%$ in the third trimester; moderate anemia was present in $1.8 \%$ in the first and third trimester, and $1.18 \%$ of severe anemia in the second trimester; the percentages found are half of those reported at the national level $(29.6 \%)$, which is a remarkable situation [3]. These results show that $15.29 \%$ of pregnant women will suffer from puerperal anemia and it will probably become moderate.

\section{Conclusions}

The pregnant women were between 20 and 30 years of age $(58,82 \%)$ and between 16 and 19 years of age $(31,76 \%)$; $50,59 \%$ were primiparous and $25,88 \%$ were multiparous; most of the pregnant women received complete supplementation $73(85,88 \%)$ with ferrous sulfate $60 \mathrm{mg}$, plus $400 \mathrm{ug}$ of folic acid. The hematocrit per trimester of pregnancy decreased from $43,52 \% \pm 4,84$ in the first trimester to $42,45 \% \pm 4,25$ in the second trimester, decreasing to $42,26 \% \pm 3,57$ in the third trimester; $50 \%$ of the pregnant women had a hematocrit lower than $43,80 \%$ in the first trimester, $42.90 \%$ in the second and $39,90 \%$ in the third trimester, the most frequent hematocrit was $43,20 \%$ in the first trimester, $42.90 \%$ in the second trimester and $39.90 \%$ in the third trimester. The corrected hemoglobin reached $12,33 \mathrm{~g} / \mathrm{dL} \pm 1,10$ in the first trimester which decreased to $11,95 \mathrm{~g} / \mathrm{dL} \pm 1,02$ in the second and $11,77 \mathrm{~g} / \mathrm{dL} \pm 1,08$ in the third trimester, $50 \%$ of the pregnant women had hemoglobin below $12,30 \mathrm{~g} / \mathrm{dL}$ in the first trimester, $12,00 \mathrm{~g} / \mathrm{dL}$ in the second and third trimester. Mild anemia was found to be 3,53\% in the first trimester, rising to $9,41 \%$ in the second and reaching $15,29 \%$ in the third trimester, moderate anemia was a minimum of $1,18 \%$ in both the first and third trimester, while severe anemia 
was found to be $1,18 \%$ only in the second trimester, numbers lower than those reported at the national level. The hemodynamic status of the pregnant women has suffered decreases in both hematocrit and hemoglobin; likewise, anemia is in lower proportion to the national figures, however, it seems that the hemoglobin ranges reached in the third trimester risk anemia in the postpartum period.

\section{REFERENCES}

[1] Guyton AC, Hall JE, Guyton AC. Tratado de fisiología médica: novena edición. Madrid: McGraw-Hill/Interameri cana de España; 1996.

[2] Gonzales GF, Gonzales C. Iron, anemia and erythrocytosis in pregnant women at high altitude: risk in the mother and the newborn. Rev Peru Ginecol Obstet. 2012;58(4):329-40.

[3] INEI, PERU. Peru: Demographic and Family Health Survey 2017 - National and Regional. Statistical. Lima: National Institute of Statistics and Informatics, Demographic survey of family health- ENDES [Internet]. [cited $2021 \mathrm{Feb}$ 1]. Available from: https://www.inei.gob.p e/media/MenuRecursivo/publicaciones_digitales/Est/Lib15 26/libro.pdf

[4] MINSA, PERU. Technical Guide: Clinical practice guide for the diagnosis and treatment of iron deficiency anemia in children and adolescents in primary care health facilities [Internet]. [cited 2021 Feb 1]. Available from: http://bvs.minsa.gob.pe/local/MINSA/3932.pdf

[5] Fonseca C, Emily K. Correlation of the level of hemoglobin pre and postpartum and factors associated with the clinical picture of anemia in postpartum women served at the honorio delgado espinoza regional hospital.arequipa,2013. Univ Católica St María - UCSM [Internet]. 2014 Mar 26 [cited 2020 Mar 19]; Available from: https://tesis.ucsm.edu.pe:80/repositorio/handle/UCSM/468 9

[6] Boccio J, Concepción Páez M, Zubillaga M, Salgueiro J, Goldman C, Domingo B, et al. Causes and consequences of iron deficiency on human health. Arch Latinoam Nutr. 2004 Jun;54(2):165-73.

[7] Manjarrés Correa LM, Parra Sosa BE, Díaz Cadavid A, Restrepo Mesa SL, Mancilla López LP. Iron and folate intake during pregnancy and its relationship with maternal biochemical indicators. Iatreia. 2012;25(3):192-202.

[8] Jiménez Acosta SM, Rodríguez Suárez A, Pita Rodriguez G Prevalence of anemia during pregnancy in Cuba. Evolution in 15 years. Rev Esp Nutr Comunitaria. 2014;42-7.

[9] Gonzales GF, Olavegoya P. Pathophysiology of anemia during pregnancy: anemia or hemodilution? Rev Peru Ginecol Obstet. 2019 Oct;65(4):489-502.

[10] Vega Gonzales EO, Cubas Romero FC, Ampuero Barzola $\mathrm{CM}$. Iron consumption and hemoglobin level in puerperal women of the Hipólito Unanue National Hospital 2018. Univ César Vallejo [Internet]. 2018

[11] Cárdenas S. Anemia in pregnant women as a risk factor associated with low birth weight at the Luis N. Sáenz National Police Hospital between the years 2014 - 2015 [Internet]. [cited 2019 Feb 18]. Available from: https://estadisticas.minsalud.gob.bo/Reportes_Vigilancia/F orm_Vigi_2016_302a.aspx

[12] Vásquez J, Magallanes J, Camacho B, Meza G, Villanueva $\mathrm{M}$, Corals $\mathrm{C}$, et al. Hemoglobin in pregnant women and its association with maternal and newborn characteristics: 6 .

[13] Canalejo K, Tentoni J, Aixalá M, Jelen AM. Blood count reference values in pregnant women, with current technology. :4.

[14] Peñuela OA. Hemoglobin: a model molecule for the researcher. Colomb Médica. 2005;36(3):215-25.

[15] Practical hematology blood count [Internet]. StuDocu. [cited $2021 \quad$ Feb 1]. Available from: https://www.studocu.com/pe/document/universidad-alas-p eruanas/inmunologia/practica/hemograma-hematologia-pra ctica/5024480/view

[16] Perutz MF. Structure and mechanism of haemoglobin. Br Med Bull. 1976 Sep;32(3):195-208.

[17] Restrepo M SL, Mancilla L LP, Parra S BE, Manjarrés C LM, Zapata L NJ, Restrepo Ochoa PA, et al. Evaluation of the nutritional status of pregnant women who participated in a food and nutrition program. Rev Chil Nutr. 2010 Mar;37(1):18-30.

[18] Milman N. Pathophysiology and impact of iron deficiency and anemia in pregnant women and newborns/infants. Rev Peru Ginecol Obstet. 2012;58(4):293-312.

[19] Rubio-Romero JA, Ruiz-Parra AI, Martínez F, Muñoz-Restrepo J, Muñoz LA, Arévalo-Rodríguez I, et al. Clinical practice guideline for the early detection of abnormalities during labor, normal and dystocic delivery care. Rev Colomb Obstet Ginecol. 2013 Dec 20;64(4):379424.

[20] Becerra C, Gonzales GF, Villena A, de la Cruz D, Florián A. Prevalence of anemia in pregnant women, Regional Hospital of Pucallpa, Peru. Rev Panam Salud Pública. 1998 May;3:285-92.

[21] Supo DJ, Zacarías MH. SCIENTIFIC RESEARCH METHODOLOGY: For Health Sciences and Social Sciences. 2020. 352 p.

[22] Scientific Research Seminars: Research Methodology for Health Sciences: Jose Supo: 9781477449042 [Internet]. [cited 2021 Feb 1]. Available from: https://www.bookdepository.com/es/Seminarios-de-Investi gacion-Cientifica-Metodologia-de-La-Investigacion-ParaLas-Ciencias-de-La-Salud-Jose-Supo/9781477449042

[23] Aquice A, Pamela I. Relationship of hemoglobin, hematocrit and serum iron levels before and after eutocical delivery in pregnant women served at the obstetrics-gynecology service of hospital edmundo escomel, arequipa 2014. Univ Católica St María - UCSM [Internet]. 2015 Jan 27 [cited 2020 Mar 19]; Available from: https://tesis.ucsm.edu.pe:80/repositorio/ha ndle/UCSM/3431

[24] Gonzales GF, Gonzales C. Iron, anemia and erythrocytosis in pregnant women at high altitude: risk in the mother and the newborn. Rev Peru Ginecol Obstet. 2012; 58(4):329-40. 